Brit. J. industr. Med., 1956, 13, 6.

\title{
A REPORT ON THE ABSENCE OF PNEUMOCONIOSIS AMONG WORKERS IN PURE LIMESTONE
}

\author{
BY \\ S. BRIDGE DAVIS and G. NAGELSCHMIDT \\ From the Medical Inspectorate of Mines and Quarries, Manchester, and the \\ Safety in Mines Research Establishment, Sheffield \\ (RECEIVED FOR PUBLICATION JULY 27, 1955)
}

It is generally believed that exposure to limestone dust does not present a pneumoconiosis hazard. However, Doig (1955) has recently described cases of silicosis amongst limestone workers after prolonged exposure to high dust concentrations. The limestones concerned contained from 5 to $15 \%$ quartz as impurity, and dissolution of the calcium carbonate in the lung would leave a quartz-rich residue which may well have caused the disease. If this interpretation were correct no pneumoconiosis should occur amongst workers in pure limestone. It was decided to test this by radiological and clinical examination of men who should have been exposed to high dust concentrations of pure limestone for long periods of time.

The purest limestone found in sufficient quantity for commercial use in the British Isles occurs in the Buxton area of Derbyshire. This limestone is of the Lower Carboniferous age and contains upwards of $97 \%$ of calcium carbonate. Its quartz content is usually below $1 \%$. There are many quarries and grinding plants in the area but the basic processes are identical in most plants. The quarried rock is broken by crushers, screened, and dried. The dried product is pulverized and bagged. Dust conditions vary with the type of machinery and ventilation systems in use. In general,'the smaller and older plants are more dusty than the large modern ones. Rotary driers, pulverizers, and bagging machinery produce most of the dust but crushers and conveyors also can be very dusty. The ventilation systems usually discharge the dust into the open air above roof height, and its further dispersal is very much affected by wind and weather. There is a definite haze of dust in many plants and a covering of dust over machinery, ladders, and floors. The faces, hands, and clothing of the workers are covered by a layer of dust.

In the course of the survey made in the autumn of 1954 a large number of quarries and grinding plants were visited.

The names of 29 men with histories of sufficiently long exposures to pure limestone dust were obtained. They were interviewed individually and occupational histories were taken. Fifteen had to be rejected because they had worked either with gritstone, chert, igneous rock, or in a brickworks at some time or other. This left a group of 14 men for clinical and $x$-ray examination ; they had been exposed to heavy dust concentrations for periods varying from 12 to 35 years and had worked at eight plants given in code letters $\mathrm{A}$ to $\mathrm{H}$ in Tables 1,2 , and 3.

The 14 men were examined at the Manchester Royal Infirmary. Full-size radiographs were taken, and thorough clinical examinations were made. The main result of the work was that no trace of abnormalities due to dust could be seen on the radiographs nor was there any clinical sign of pneumoconiosis or of chronic bronchitis. Detailed results are given in Table 1.

\section{Dust Composition and Concentration}

Samples of fine dust were obtained from the eight plants and analysed for quartz content ; the results are given in Table 2, from which it will be

TABLE 2

QUARTZ ANALYSIS OF LIMESTONE SAMPLES

\begin{tabular}{|c|c|c|}
\hline Source & Acid Insoluble & $\underset{(\%)}{\text { Quartz in Sample }}$ \\
\hline $\begin{array}{cc}\text { Plant } & \mathbf{A} \\
, " & \mathbf{B} \\
, " & \mathbf{D} \\
, " & \mathbf{E} \\
, & \mathbf{F} \\
, & \mathbf{H}\end{array}$ & $\begin{array}{l}0.3 \\
3.9 \\
2.3 \\
1.4 \\
1.7 \\
0.8 \\
0.5 \\
0.4\end{array}$ & $\begin{array}{l}0 \cdot 1 \\
1 \cdot 1 \\
0 \cdot 3 \\
0 \cdot 3 \\
0 \cdot 2 \\
0 \cdot 2 \\
0 \cdot 2 \\
0 \cdot 2\end{array}$ \\
\hline
\end{tabular}


TABLE 1

CLINICAL FINDINGS OF 14 MEN EXPOSED TO PURE LIMESTONE DUST

\begin{tabular}{|c|c|c|c|c|c|c|c|}
\hline Plant & Worker & Age & $\begin{array}{c}\text { Exposure } \\
\text { (years) }\end{array}$ & $\begin{array}{l}\text { Occupational } \\
\text { History }\end{array}$ & $\begin{array}{l}\text { Past Medical } \\
\text { History }\end{array}$ & $\begin{array}{c}\text { Clinical } \\
\text { Examination }\end{array}$ & $\begin{array}{l}\text { Radiograph of } \\
\text { Chest }\end{array}$ \\
\hline A & J.P. & 51 & 35 & $\begin{array}{l}\text { Has been in every } \\
\text { process of industry } \\
\text { and heavily exposed } \\
\text { to limestone dust }\end{array}$ & $\begin{array}{l}\text { In the past had } 2 \text { years } \\
\text { gastric illness but } \\
\text { apart from this noth- } \\
\text { ing else }\end{array}$ & $\begin{array}{l}\text { Chest N.A.D. }{ }_{2}^{\text {Chest }} \text { in. } \\
\text { expansion } 2 \text {. } \\
\text { B.P. } 130 / 80 \mathrm{~mm} . \mathrm{Hg} \text {. } \\
\text { Weight } 11 \text { st. } 8 \mathrm{lb} \text {. }\end{array}$ & Normal \\
\hline $\mathbf{A}$ & T.A.G. & 51 & 35 & $\begin{array}{l}\text { Has always been a } \\
\text { quarryman : fitter's } \\
\text { mate, crusherman, } \\
\text { dust tipping (quarry } \\
\text { spoil), quarry face } \\
\text { (stone filler), plate- } \\
\text { layer (for tubs), } \\
\text { plant attendant }\end{array}$ & Nil & $\begin{array}{l}\text { Chest N.A.D. }{ }_{3}^{\text {Chest }} \\
\text { expansion in. } \\
\text { B.P. } 130 / 80 \mathrm{~mm} . H \mathrm{Hg} . \\
\text { Weight } 12 \text { st. } 1 \mathrm{lb} \text {. }\end{array}$ & Normal \\
\hline $\mathbf{A}$ & S.I.W. & 58 & 33 & $\begin{array}{l}\text { Maintenance fitter in } \\
\text { plant. Heavy expo- } \\
\text { sure to dust }\end{array}$ & $\begin{array}{l}\text { Pneumonia at age } 30, \\
\text { otherwise no serious } \\
\text { illnesses }\end{array}$ & $\begin{array}{l}\text { Chest N.A.D. }{ }^{\text {Chest }} \\
\text { expansion } 3 \text { in. } \\
\text { B.P. } 180100 \mathrm{~mm} . \mathrm{Hg} . \\
\text { Weight } 12 \text { st. } 4 \mathrm{lb} \text {. }\end{array}$ & Normal \\
\hline $\mathbf{A}$ & J.S.W. & 52 & 27 & Plant attendant & Nil & 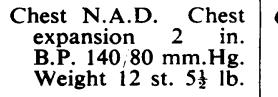 & $\begin{array}{l}\text { Old scarring in' } \mathrm{L} \text {. apex. } \\
\text { No active lesion }\end{array}$ \\
\hline B & R.H.F. & 39 & 12 & $\begin{array}{l}\text { General foreman : has } \\
\text { done all jobs in the } \\
\text { plant }\end{array}$ & $\begin{array}{l}\text { Some } 12 \text { months ago } \\
\text { began to get symp- } \\
\text { toms (of a psycho- } \\
\text { neurotic type) of } \\
\text { being unable to take } \\
\text { a deep breath, etc. } \\
\text { Was radiographed } \\
\text { at various places, } \\
\text { nothing found. Re- } \\
\text { ports that he has } \\
\text { improved consider- } \\
\text { ably over the last } \\
\text { few months }\end{array}$ & $\begin{array}{l}\text { Chest N.A.D. Chest } \\
\text { expansion } 4 \frac{1}{2} \text { in. } \\
\text { B.P. } 12075 \mathrm{~mm} \text {.Hg. } \\
\text { Weight } 11 \text { st. } 3 \frac{i}{2} \mathrm{lb} .\end{array}$ & Normal \\
\hline C & F.H.B. & 76 & 23 & $\begin{array}{l}\text { Until the age of } 52 \\
\text { worked in the } \\
\text { engineering trade. } \\
\text { Worked as a plant } \\
\text { attendant until a } \\
\text { year ago (when he } \\
\text { was } 75 \text { years of age). } \\
\text { Heavily exposed to } \\
\text { dust }\end{array}$ & Nil & $\begin{array}{l}\text { Remarkably youthful } \\
\text { man for his age. } \\
\text { Chest, occasional } \\
\text { rhonchi heard. Chest } \\
\text { expansion } 3 \text { in. } \\
\text { B.P. } 20090 \mathrm{~mm} . \mathrm{Hg} \text {. } \\
\text { Weight } 12 \text { st. } 5 \mathrm{lb} \text {. }\end{array}$ & $\begin{array}{l}\text { Both lung fields show } \\
\text { a rather exaggerated } \\
\text { pattern throughout } \\
\text { and the lung markings } \\
\text { extend peripherally } \\
\text { farther than normal. } \\
\text { Within the normal } \\
\text { limits for his age }\end{array}$ \\
\hline $\mathrm{D}$ & T.A. & 52 & 35 & $\begin{array}{l}\text { Trimming, lettering, } \\
\text { and machining } \\
\text { limestone }\end{array}$ & $\begin{array}{l}\text { At } 17 \text { years of age had } \\
\text { pleurisy with effu- } \\
\text { sion. Off } 10 \text { months. } \\
\text { No further illness }\end{array}$ & $\begin{array}{l}\text { A youthful } 52 \text {. Chest } \\
\text { N.A.D. Chest ex- } \\
\text { pansion } 3 \text { in. B.P. } \\
190 / 110 \mathrm{~mm} \text {. Hg. } \\
\text { Weight } 12 \mathrm{st} .10 \mathrm{lb} \text {. }\end{array}$ & $\begin{array}{l}\text { There is an adhesion in } \\
\text { the right costophrenic } \\
\text { angle; the lung pat- } \\
\text { tern is otherwise } \\
\text { normal }\end{array}$ \\
\hline $\mathbf{E}$ & R.L.A. & 41 & 27 & $\begin{array}{l}\text { Plant attendant and } \\
\text { bagger }\end{array}$ & $\begin{array}{l}\text { At } 14 \text { years of age had } \\
\text { bronchitis with } \\
\text { measles }\end{array}$ & $\begin{array}{l}\text { Chest N.A.D. }{ }_{2}^{\text {Chest }} \text { in. } \\
\text { expansion } 2 \text {. } \\
\text { B.P. } 12080 \mathrm{~mm} \text {. Hg. } \\
\text { Weight } 9 \text { st. } 12 \mathrm{lb} \text {. }\end{array}$ & Normal \\
\hline $\mathbf{E}$ & J.F. & 46 & 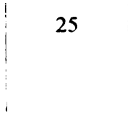 & $\begin{array}{l}\text { Plant attendant and } \\
\text { bagger }\end{array}$ & Nil & $\begin{array}{l}\text { Chest N.A.D. Chest } \\
\text { expansion } 2 \frac{1}{2} \text { in. } \\
\text { B.P.145 } 110 \mathrm{~mm} . H g . \\
\text { Weight } 10 \text { st. } 9 \mathrm{lb} \text {. }\end{array}$ & Normal \\
\hline $\mathbf{F}$ & W.G. & 35 & 16 & Limestone bagger & Nil & $\begin{array}{l}\text { Chest N.A.D. }{ }_{3}^{\text {Chest }} \\
\text { expansion } \\
\text { B.P. } 130 / 90 \mathrm{~mm} . \mathrm{Hg} . \\
\text { Weight } 11 \text { st. }\end{array}$ & Normal \\
\hline G & W.H.P. & 55 & 34 & Limestone crusherman & Nil & $\begin{array}{l}\text { Some kyphosis. Chest } \\
\text { N.A.D. Chest ex- } \\
\text { pansion } 2 \text { in. B.P. } \\
210 / 130 \mathrm{~mm} \text {. Hg. } \\
\text { Weight } 10 \text { st. } 8 \mathrm{lb} \text {. }\end{array}$ & $\begin{array}{l}\text { Left diaphragm higher } \\
\text { than the right. No } \\
\text { pulmonary lesion }\end{array}$ \\
\hline G & G.W.E. & 52 & 27 & $\begin{array}{l}\text { Plant attendant, bag- } \\
\text { ger, and crusher }\end{array}$ & Nil & $\begin{array}{l}\text { Chest N.A.D. Chest } \\
\text { expansion } 2 \frac{1}{2} \text { in. } \\
\text { B.P. } 140 / 85 \mathrm{~mm} . \mathrm{Hg} . \\
\text { Weight } 10 \text { st. } 10 \mathrm{lb} .\end{array}$ & Normal \\
\hline $\mathbf{H}$ & C.C.G. & 44 & 21 & Plant attendant & $\mathrm{Nil}$ & $\begin{array}{l}\text { Chest N.A.D. Chest } \\
\text { expansion } 1 \frac{1}{2} \text { in. } \\
\text { B.P. } 130 / 85 \mathrm{~mm} . \mathrm{Hg} . \\
\text { Weight } 11 \text { st. } 6 \mathrm{lb} \text {. }\end{array}$ & Normal \\
\hline $\mathbf{H}$ & J.W.H. & 47 & 20 & Plant attendant & Nil & $\begin{array}{l}\text { Marked kyphosis. } \\
\text { Chest N.A.D. Chest } \\
\text { expansion } 3 \text { in. } \\
\text { B.P. } 130,75 \mathrm{~mm} . \mathrm{Hg} \text {. } \\
\text { Weight } 8 \text { st. } 12 \mathrm{lb} \text {. }\end{array}$ & $\begin{array}{l}\text { The left costophrenic } \\
\text { angle blunt. No-pul- } \\
\text { monary lesion }\end{array}$ \\
\hline
\end{tabular}


seen that one sample had $1 \cdot 1 \%$ of quartz and all others had less than $0.5 \%$.

At three of the plants thermal precipitator samples were taken during working hours. These samples were taken at breathing level at places where men worked or passed, usually near a source of airborne dust. At two of the plants two thermal precipitators were used, sampling at approximately the same time within a few feet of each other.

The thermal precipitator samples were evaluated to give the concentration of particles within the size range 0.5 to 5 microns (Table 3). With some of the samples a complete size distribution of the particles was measured.

\section{TABLE 3}

THERMAL PRECIPITATOR DUST COUNTS AT THREE LIMESTONE PLANTS

\begin{tabular}{|c|c|c|c|}
\hline \multirow[t]{2}{*}{ Plant } & \multirow[t]{2}{*}{ Sampling Point } & \multicolumn{2}{|c|}{$\begin{array}{c}0.5-5 \mu \text { particles } \\
\text { per cc. }\end{array}$} \\
\hline & & $(\mathbf{I})^{*}$ & (II)* \\
\hline A & $\begin{array}{l}\text { Mixing platform .. . } \\
\text { Discharge from secondary crusher } \\
\begin{array}{l}\text { Above coarse dust bunker } \\
\text { Vibratory screen platform }\end{array} \\
\begin{array}{l}\text { Two-foot cone crusher } \\
\text { Discharge from vertical driers }\end{array} \\
\begin{array}{l}\text { Loading and stacking bags } \\
\text { Between mills .. }\end{array} \\
\begin{array}{l}\text {.. } \\
\text {. . }\end{array}\end{array}$ & $\begin{array}{r}1,740 \\
560 \\
2,350 \\
1,250 \\
1,560 \\
690 \\
240 \\
3,640\end{array}$ & $\begin{array}{r}355 \\
555 \\
3,350 \\
2,030 \\
1,470 \\
1,790 \\
790 \\
310 \\
2,420\end{array}$ \\
\hline D & 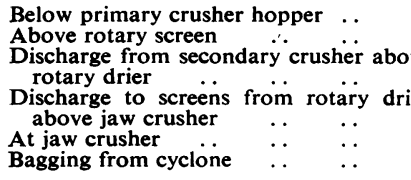 & $\begin{array}{r}590 \\
515 \\
3,620 \\
3,240 \\
5,920 \\
760\end{array}$ & $\begin{array}{r}460 \\
60 \\
2,450 \\
2,280 \\
5,390 \\
470\end{array}$ \\
\hline $\mathrm{F}$ & 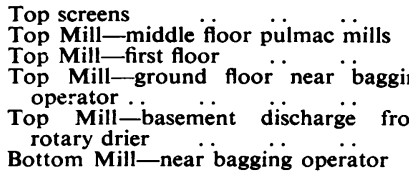 & $\begin{array}{l}4,480 \\
5,390 \\
5,030 \\
3,480 \\
3,620 \\
2,650\end{array}$ & $\begin{array}{l}- \\
- \\
-\end{array}$ \\
\hline
\end{tabular}

Many of the samples showed high concentrations of dust, and those at plant $F$ were of the order of 3,000 to 5,000 particles per cc. Even at Plant A, where extensive dust extraction equipment was installed, some of the dust counts were quite high. These results indicate the level of airborne dust concentrations to which workmen in the plants are exposed. The concentrations may vary appreciably with time, depending mainly on the amount and direction of ventilation and the degree of activity.
The size distributions were typical of airborne dust. In all cases over $80 \%$ of the particles were below 5 microns in size, and over $20 \%$ below $0 \cdot 25$ micron.

\section{Comment}

Dust concentrations during the last 30 years are not known but it is very likely that they were higher than those found at the present time when much attention is paid to dust suppression. Nevertheless, many of the figures measured now showed dust counts of the order of 3,000 particles per cc. of a size between 0.5 and 5 microns. The quartz percentage of this dust was, however, extremely low. There was no sign of accumulated dust in the lungs of any of the men examined and no clinical evidence of bronchitis. It appears very likely that calcium carbonate can be eliminated from the lungs, probably by dissolution as calcium bicarbonate. It follows from these observations that long exposure to extremely high dust concentrations of pure limestone does not lead to any fibrosis of the lung.

\section{Summary}

A clinical and an $x$-ray examination were carried out on 14 men who had worked in pure limestone for periods varying from 12 to 35 years; no evidence of pneumoconiosis was found although the dust counts showed many thousands of particles between 0.5 and 5 microns in the atmosphere to which the men were exposed.

This survey would have not been possible without the wholehearted cooperation of management, union officials, and workers at the quarries.

We wish to thank Professor R. E. Lane, Nuffield Department of Occupational Health, Manchester University, and Dr. E. D. Gray, radiologist, Manchester Royal Infirmary, for the clinical and radiological investigations ; our thanks are also due to Mr. R. H. Griffiths, H.M. Inspector of Quarries, for help in selecting the quarries ; to Mr. W. Staton, H.M. Senior Inspector for Special Development Duties (Dust); to Dr. J. T. Burdekin and Mr. S. R. Asquith, Safety in Mines Research Establishment, for doing the dust counts, and to the Ministry of Fuel and Power for permission to publish. The cost of this investigation was met by a grant from the Medical Research Council.

\section{REFERENCE}

Doig, A. T. (1955). British Journal of Industrial Medicine, 12, 206. 